\title{
GASTCOLUMN
}

\section{Het hegemoniale discours van de participatiesamenleving.}

\author{
Kritiek van de 'doe-democratie'*
}

Ido de $\operatorname{Haan}^{* *}$

Om de paar jaar duikt er in het publieke debat een nieuw concept op dat als panacee voor een hele reeks maatschappelijke problemen wordt beschouwd. De laatste tijd beleeft de term 'participatie' een opmerkelijke terugkeer, met allerlei conceptuele varianten, zoals actief burgerschap, de vitale samenleving, de participatiesamenleving of, zoals het in kreupel beleidsjargon wordt genoemd, de 'doe-democratie'.

Het is opvallend hoe enthousiast het thema van actief burgerschap is omarmd door het Nederlandse politieke establishment. In juni 2013 presenteerde het kabinet-Rutte zijn visie op de participatiesamenleving in Doe-democratie. Kabinetsnota ter stimulering van een vitale samenleving. Dit rapport was het sluitstuk van een reeks eerdere publicaties met dezelfde strekking. In mei 2012 publiceerde de Wetenschappelijke Raad voor het Regeringsbeleid het rapport Vertrouwen in burgers, een halfjaar later gevolgd door het rapport van het Sociaal en Cultureel Planbureau Beroep op de burger, met de ondertitel Minder verzorgingsstaat, meer eigen verantwoordelijkheid?. De twijfel die wordt uitgedrukt met het vraagteken achter deze titel was al verdwenen in het rapport van de Raad voor het openbaar bestuur, waarin het ging om Loslaten in Vertrouwen. Naar een nieuwe verhouding tussen overheid, markt en samenleving (november 2012). In dezelfde geest presenteerde de Raad voor Maatschappelijke Ontwikkeling Terugtreden is vooruitzien, maatschappelijke veerkracht in het publiek domein (juli 2013).

De eensgezindheid over het nut van actief burgerschap was ook al tot uitdrukking gekomen in de brief die negen (deels bovengenoemde) adviesraden op 6 december 2012 aan de regering stuurden, met de vraag 'of zij wel voldoende gebruikmaakt van de vitaliteit van de samenleving en van de kennis en expertise van burgers'. Deze consensus werd bekroond met de motie-Voortman die op 20 december 2012 door de Tweede Kamer unaniem werd aangenomen, met daarin het verzoek aan het kabinet om 'te concretiseren of en, zo ja, op welke manier zij van plan is zeg-

* $\quad$ Dit stuk is een bewerking van een lezing gehouden op het symposium Citizenship 3.0: citizenship and participation, KNAW, 16 mei 2014.

** Prof. dr. Ido de Haan is hoogleraar politieke geschiedenis aan het departement Geschiedenis en Kunstgeschiedenis van de Universiteit Utrecht. E-mail: i.dehaan@uu.nl. 
genschap over te dragen aan burgers en hoe zij deze overdracht wil bevorderen op lokaal niveau'.

Kortom: hier is sprake van wat gramscianen een hegemoniaal discours zouden noemen. Kenmerk daarvan is dat niet alleen the powers that be dat discours hanteren - dat is in zekere zin tautologisch - maar dat ook degenen die maatschappelijke alternatieven denken aan te reiken de taal van de macht overnemen. Want participatie is niet alleen de slogan van de bestuurlijke elite op zoek naar een gezamenlijke missie, maar ook de rallying cry van activisten, buurtwerkers en verenigingsbesturen die zichzelf presenteren als voorhoede van het nieuwe samen-doen. Soms wordt die samenloop van hegemoniale en subalterne motieven gethematiseerd. Zo schilderden de activisten die een voormalig dierenasiel in Amsterdam-Oost hadden gekraakt en daar tegen de zin van het lokale bestuur een centrum voor buurtactiviteiten wilden inrichten, op het dak van het gebouw de kreet 'Hierr!! is je participatie!!'. Maar meestal gaat de top-downcampagne voor actief burgerschap gelijk op met bottom-up-initiatieven van de participatiesamenleving. In deze maatschappelijke eensgezindheid gaat al snel verloren met welke kosten, maar ook met welke belangen de participatiesamenleving gepaard gaat, en wordt voorbijgegaan aan de inconsistenties die het beroep op de actieve burgers in zich bergt.

Wat wordt er in al deze stukken met participatie bedoeld? Om te beginnen gaat het hier om de herneming van het thema dat eerder werd besproken onder noemers als 'sociale vernieuwing' en de 'zorgzame samenleving'. Het betreft dan de gedachte dat de burgers hun lot in eigen handen moeten nemen en minder een beroep zouden moeten doen op ondersteuning van de staat. Deze overgang van verzorgingsstaat naar participatiesamenleving wordt met een reeks van argumenten gerechtvaardigd: maatschappelijke trends zoals veroudering van de bevolking, individualisering en globalisering hebben de houdbaarheid van de klassieke verzorgingsstaat aangetast. De financiële beperkingen van de staat nopen tot grotere eigen verantwoordelijkheid van de burger. De geïndividualiseerde burger wil niet langer sociale zekerheid als standaardconfectie, maar zorg op maat en naar eigen inzicht, dus ook op basis van een eigen risico analyse. Burgers willen grotere zeggenschap en moeten dat ook krijgen, omdat ze anders hun steun aan de verzorgingsstaat onttrekken.

Dat is de link naar een tweede lijn in de discussie. Dan is de roep om 'participatie' een voortzetting van de niet-aflatende kritiek op de vertegenwoordigende democratie. Ook hier zijn de argumenten bekend: de vertegenwoordigende democratie is niet in staat maatschappelijke belangen op adequate manier te representeren. De volksvertegenwoordiging vormt een gesloten bolwerk, een eenpartijstaat met eigen belangen, waarin politici vooral gehecht zijn aan het pluche. Democratie vergt meer dan eens in de vier jaar stemmen. Burgerschap komt tot uitdrukking in daadwerkelijke participatie, in referenda, burgerfora, interactieve beleidsvorming. In de 'doe-democratie' komen beide vormen van participatie samen: eigen verantwoordelijkheid nemen is een vorm van zelfbestuur. 
Zonder de specificiteit van het huidige hegemoniale discours te ontkennen, leert een blik op de geschiedenis dat dit pleidooi voor actief burgerschap diep verankerd is in de Nederlandse democratie. Al vanaf het begin van de moderne verzorgingsstaat en de massademocratie, dus vanaf het einde van de negentiende eeuw, keert dit op gezette tijden terug. Je zou kunnen zeggen dat de oprichting van politieke partijen, vakbonden, coöperaties en overlegorganen rond 1880 de eerste poging was om de band te herstellen tussen staat en samenleving, die na een halve eeuw van liberaal laisser faire en de afbraak van intermediaire instituties verloren was gegaan. In de jaren dertig van de twintigste eeuw ging de kritiek op de parlementaire democratie voor het eerst gepaard met een pleidooi voor referenda, industrial democracy en de inschakeling van direct betrokkenen en deskundigen in corporatieve vormen van democratie - opnieuw met als doel de bevolking, nu opgedeeld in functionele kringen, direct vorm te laten geven aan hun eigen omgeving. Ook de roep om participatie, zelfbestuur en directe democratie van de jaren zestig was een voorbode van de participatiesamenleving die nu zo hartelijk wordt omarmd.

Het lijkt een historische dooddoener om te zeggen dat het pleidooi voor een actief burgerschap van alle tijden is. Dat is het niet: elk van deze episodes leert dat het participatoir enthousiasme een reactie is op structurele spanningen in de moderne democratische staat. De belofte van politieke gelijkheid botst met de realiteit van sociale verschillen; de verdediging van het algemeen belang vergt compromissen die ten koste gaan van bijzondere belangen; de bescherming van zwakkeren gaat ten koste van de vrijheid, niet alleen van de sterken wier macht aan banden wordt gelegd, maar ook van de zwakken die moeten passen in de mal van gebureaucratiseerde zorg.

Deze spanningen treffen in de eerste plaats democratisch gekozen volksvertegenwoordigers. Zij krijgen het verwijt niet in staat te zijn effectief maatschappelijke belangen te verdedigen, sociale ongelijkheid weg te nemen en daadwerkelijke vrijheid te realiseren. Naast een gebrek aan effectiviteit lijden zij aan een legitimatietekort. Zij ontberen zowel outputlegitimatie - real freedom for all - als inputlegitimatie - adequate vertegenwoordiging van maatschappelijke belangen.

In dat licht bezien is participatie, opgevat als eigen verantwoordelijkheid van burgers, de oplossing voor gebrek aan effectiviteit, en participatie als zelfbestuur een antwoord op gemis aan legitimiteit. Kort gezegd: wat politici niet kunnen, zouden ze ook niet moeten willen, maar aan burgers moeten overlaten. Of die burgers dan wel effectief en legitiem kunnen optreden, is van secundair belang. Dat noopt derhalve tot enige scepsis ten aanzien van het oplossend vermogen dat aan 'participatie' op dit moment wordt toegedicht. Het enthousiasme voor de term is wellicht eerder een symptoom van een probleem dan onderdeel van een oplossing.

Dat vermoeden wordt versterkt door twee opvallende bijkomende kenmerken van het participatiediscours. Het eerste is de voortdurende klacht over bureaucratische belemmeringen die initiatieven van actieve burgers frustreren. Meestal worden die belemmeringen toegeschreven aan een hardleerse overheid die nog niet 
geleerd heeft 'los te laten', in het 'vertrouwen' dat de burgers hun eigen boontjes kunnen doppen. Die optimistische verwachting gaat voorbij aan de ijzeren wet van de deregulering, die voorspelt dat elke deregulering gepaard gaat met re-regulering. Of het nu gaat om de decentralisatie van bevoegdheden, de privatisering van de zorg of de inschakeling van burgers in het beheer van openbare diensten steeds weer gaat dit gepaard met nieuwe vormen van toezicht die de kwaliteit en stabiliteit van dienstverlening en de rechtvaardigheid in de verdeling van maatschappelijke goederen moeten waarborgen. De participatiesamenleving is ook een 'monitory democracy', waarin verantwoording niet langer aan het begin, in de aansturing van maatschappelijke instituties, maar uitsluitend achteraf, in de controle op maatschappelijke uitkomsten, plaatsvindt.

Een tweede kenmerk van het participatiediscours is de opvallende selectiviteit. Burgers moeten participeren in de buurt, het verenigingsleven, de mantelzorg en het betaald werk, maar ongereguleerde vrijplaatsen van actief burgerschap worden slechts getolereerd als broedplaatsen van maatschappelijke innovatie, die liever geen permanente status moeten krijgen. En bovendien ontbreken in het participatiediscours tal van maatschappelijke domeinen waar wat meer burgerdeugd niet zou misstaan. Het zou verfrissend zijn als in het pleidooi voor actief burgerschap de bankwereld, de hedge funds of de pensioenfondsen centraal hadden gestaan, maar klaarblijkelijk is in deze sectoren de overheid al voldoende teruggetreden ten gunste van een participatiemaatschappij waarin de meest vermogende aandeelhouders het voor het zeggen hebben.

Het participatiediscours is ook intern tegenstrijdig. De regering stelt in haar nota over de 'doe-democratie' dat haar pleidooi voor de participatiesamenleving is ingegeven door drie ontwikkelingen: het toenemend zelforganiserend vermogen van de samenleving, de terugtredende overheid en de stijgende behoefte aan sociale binding. Dat zijn nogal uiteenlopende kwesties, waarachter zeer uiteenlopende opvattingen van participatie schuilgaan. De veronderstelling dat participatie de oplossing is voor een gebrek aan sociale binding past binnen een conservatief discours, waarin het gezins-, kerk- en verenigingsleven de context vormen waarbinnen sociale betrokkenheid kan ontstaan. Dit gedachtegoed ligt bijvoorbeeld ten grondslag aan de Wet maatschappelijke ondersteuning, waarin de zorg voor hulpbehoevenden in de eerste plaats de verantwoordelijkheid is voor mantelzorgende gezinsleden en buren, en pas in tweede instantie voor de (lokale) overheid. Zo'n vorm van participatie kan alleen gestalte krijgen als die sterke banden er ook daadwerkelijk zijn.

Dat staat op gespannen voet met de gedachte dat participatie een antwoord is op de terugtredende overheid. Die gedachte past eerder in een neoliberaal vocabulaire. Het grootste probleem is dan niet een gebrek aan sociale binding, maar de ruimte die een te vrijgevige overheid biedt aan free riders. Participatie wordt dan in de eerste plaats opgevat als arbeidsdeelname, waarbij de bescherming die de verzorgingsstaat biedt tegen de willekeur van de arbeidsmarkt weggenomen moet worden om arbeidsparticipatie af te dwingen. Een tweede vorm van participatie is die van consumenten, die in staat moeten zijn een eigen afweging te maken van 
de risico's en waarde die ze toekennen aan sociale zekerheid, zorg, onderwijs en al die andere voorzieningen van de verzorgingsstaat. In beide gevallen staan individuele inzet en afweging centraal, en worden sociale verbanden die een dergelijke autonomie inperken als probleem opgevat: iemand die niet werkt omdat hij zijn naasten verzorgt kan geen aanspraak maken op ondersteuning.

Ten slotte is er ook nog het idee dat participatie een uitdrukking is van zelforganiserend vermogen van de samenleving. Je zou dit een sociaaldemocratisch perspectief kunnen noemen, en wellicht dat we hier stuiten op de kern van de 'doedemocratie', waarin eigen verantwoordelijkheid gekoppeld is aan zeggenschap. Een dergelijk perspectief gaat uit van de gedachte dat beleidsvorming niet langer plaatsvindt op basis van een voorafgaande analyse en doelstelling, maar gaandeweg, interactief en in samenhang met de uitvoering van sociale taken vorm krijgt - frontlijnsturing in plaats van beleidssturing. Participatie vindt in deze opvatting vooral plaats binnen de eigen leefomgeving, wijk of buurt. Ook dit staat weer op gespannen voet met allerlei functionele maar vooral ook levensbeschouwelijke verbanden - kan er op wijkniveau besloten worden dat de politie op protestantschristelijke grondslag de openbare orde bewaart? Bovendien is een dergelijke conceptie uiterst kwetsbaar voor de grotere mobiliteit die het neoliberale discours veronderstelt: moet de wijk mensen onderhouden die elders prima hun brood zouden kunnen verdienen? Dergelijke ideologische verschillen leiden derhalve tot zeer uiteenlopende en deels ook conflicterende verwachtingen ten aanzien van de participatie van burgers.

Participatie lijkt ten slotte ook geen levensvatbare zelfstandige samenlevingsvorm op te leveren. Zoals steeds weer benadrukt wordt in de studies die aan de 'doe-democratie' ten grondslag liggen, vraagt participatie nogal wat van mensen: in de 'doe-democratie' wordt deels afstand gedaan van de egalitaire normen die aan de democratische staat ten grondslag liggen, ten gunste van een eigen weerbaarheid van burgers. Het lijkt erop dat in een participatiesamenleving de scheidslijn alleen maar groter wordt tussen mondige, behendige, hoogopgeleide burgers met veel sociaal en financieel kapitaal enerzijds, en onmondige, onbeholpen, laagopgeleide en sociaal geïsoleerde, arme burgers anderzijds. Dat wordt ook erkend in de brief over de participatiesamenleving die het kabinet-Rutte op 7 april 2014 aan de Kamer stuurde. In antwoord op de zorg dat de participatiesamenleving vooral een 'zoek het zelf maar uit'- samenleving zou zijn, stelde het kabinet dat 'bijzondere aandacht nodig [is] voor mensen die in de situatie komen dat zij niet kunnen participeren, omdat zij ziek zijn, geen netwerk hebben of anderszins onvoldoende toegerust zijn. Het kabinet onderkent het belang dat deze mensen een beroep kunnen doen op de overheid en benadrukt dat de verzorgingsstaat blijft bestaan. Buiten twijfel staat dat goede voorzieningen voor een ieder beschikbaar zullen blijven.'

Een dergelijke verzekering is misschien een opluchting voor diegenen die een verdere uitholling van de verzorgingsstaat vrezen, maar zorgt er tegelijkertijd voor dat de overheidspropaganda voor de participatiesamenleving het wantrouwen voedt van minder weerbare burgers ten aanzien van de vertegenwoordigende 
democratie. Vanwaar het enthousiasme voor het zelf-doen, als dit niet weggelegd is voor diegenen die het niet zelf kunnen? Als de verzorgingsstaat voor die groep onontbeerlijk blijkt, moeten we dan maar leven met de tekortkomingen ervan, die juist breed zijn uitgevent opdat de voordelen daar zo positief mogelijk bij afsteken? Zo bezien is de lokroep van de 'doe-democratie' vooralsnog eerder het bewijs van het onvermogen van de staat dan een overtuigend pleidooi voor het zelfoplossend vermogen van de burgers. 